\title{
Strategi Penyelesaian Konflik Irigasi di Kabupaten Tanah Datar (Studi Masyarakat Petani Nagari Pangian )
}

\author{
Sri Rahayu, Susi Fitria Dewi, Henni Muchtar \\ Program Studi Pendidikan Pancasila dan Kewarganegaraan \\ Universitas Negeri Padang \\ E-mail: srirahayu950920@gmail.com
}

\begin{abstract}
ABSTRAK
Penelitian ini bertujuan mengungkapan strategi penyelesain konflik antara masyarakat petani dengan perusahaan pelaksana proyek Daerah Irigasi Batang Sinamar yaitu perusahaan PT. Waskita Karya Basuki Brahmanta Putra Join Operation terkait dampak pembangunan proyek Daerah Irigasi Batang Sinamar di Nagari Pangian Kecamatan Lintau Buo Kabupaten Tanah Datar. Penelitian ini merupakan penelitian deskriptif kualitatif dimana pengumpulan data menggunakan teknik observasi, wawancara dan dokumentasi. Informan penelitian terdiri dari, masyarakat, pihak perusahaan, koordinator masyarakat, wali jorong Koto Gadang, wali nagari Pangian, camat Lintau Buo, WALHI Sumatera Barat, ketua PBHI Sumatera Barat, pemuda Pangian, tokoh masyarakat, Kerapatan Adat Nagari Pangian, dan perwakilan suku Nagari Pangian. Data terdiri data primer dan data sekunder. Data primer terkait dengan strategi penyelesain konflik dan data sekunder terkait dengan dokumen-dokumen pendukung yang berkaitan dengan objek kajian, selanjutnya dianalis secara kualitatif dengan tahapan reduksi, penyajian dan penarikan kesimpulan.Hasil dari penelitian menunjukkan bahwa dalam penyelesain konflik ini strategi yang digunakan adalah Non-Litigasi, dimana kedua pihak berkompromi untuk menyelesaikankan konflik ini sehingga ditemukan sebuah kesepakatan untuk dapat memenuhi setiap kebutuhan dan kepentingan kedua belah pihak yang berkonflik.
\end{abstract}

Kata Kunci: Strategi Konflik, Konflik Irigasi

\section{ABSTRACT}

This study aims to disclose conflict resolution strategies between the farming community and the company implementing the Batang Sinamar Irrigation Project, namely the company PT. Waskita Karya Basuki Brahmanta Putra Join Operation related to the impact of the project development of the Batang Sinamar Irrigation Area in Nagari Pangian Lintau Buo District, Tanah Datar Regency. This research is a qualitative descriptive study where data collection uses observation, interview and documentation techniques. The research informants included the community, the company, the community coordinator, the guardian of the Koto Gadang, the guardian of the Nagari Pangian, the head of Lintau Buo, WALHI West Sumatra, the chairman of PBHI West Sumatra, the Pangian youth, community leaders, the Kerapatan Adat Nagari Pangian, representative of the Nagari Pangian tribe and vice 
chairman of the Chaniago tribe. Data consists of primary data and secondary data. Primary data is related to conflict resolution strategies and secondary data related to supporting documents relating to the object of study, then analyzed qualitatively by stages of reduction, presentation and conclusion. The results of the study indicate that in resolving this conflict the strategy used is Non-Litigation, where both parties compromise to resolve this conflict so that an agreement is found to be able to meet every need and interest of the two parties in conflict.

Keywords : Conflict Strategy, Irrigation Conflict

\section{PENDAHULUAN}

Indonesia merupakan negara yang memiliki keanekaragaman etnis, suku, budaya dan agama yang beragam, kondisi ini menjadikan Indonesia sebagai Negara yang rentan terjadi konflik. Konflik merupakan suatu perbedaan cara pandang, bentuknya bisa berupa keluhan saja sampai pada tingkat kekerasan dan perang (Wulan, Cahya, dkk, 2004). Pihak-pihak yang berkonflik tidak hanya melibatkan antara anggota masyarakat dengan anggota masyarakat, antara perusahaan satu dengan perusahaan yang lain, konflik juga melibatkan masyarakat dan perusahaan (Wulan, Yuliana Cahya, dkk, 2004). Salah satunya konflik yang terjadi antara masyarakat Nagari Pangian Kabupaten Tanah Datar dengan perusahaan pelaksana proyek irigasi Daerah Irigasi Batang SinamarPT Waskita Karya Basuki Brahmata Putra Join Operation.

Proyek Daerah Irigasi Batang Sinamar memiliki tujuan pembangunan yaitu untuk mengoptimalkan pemanfaatan sumber air Sungai Batang Sinamar untuk usaha budidaya pertanian, meningkatkan luas lahan dan areal tanam yang dapat diolah masyarakat dengan intensifikasi pertanian menjadi dua kali tanam, dan meningkatkan produksi pertanian, pendapatan dan kesejahteraan petani khususnya di daerah Kecamatan Lintau Buo dan Kecamatan Kabupaten Tanah Datar sedangkan saran yang hendak dicapai dari pembangunan Daerah Irigasi Batang Sinamar adalah terbangunnya pengembangan air permukaan sebagai irigasi untuk mengairi lahan pertanian di daerah Kecamatan Lintau Buo Kabupaten Tanah Datar, yang melibatkan PT. Waskita Karya Basuki Brahmanta Putra Join Operation sebagai pelaksana proyek. Salah satu daerah yang dilewati proyek Daerah Irigasi Batang Sinamar adalah Nagari Pangian Kecamatan Lintau Buo Kabupaten Tanah Datar.

Dalam proses pengerjaan irigasi tersebut ternyata berimplikasi terhadap terjadinya konflik antara masyarakat dengan perusahaan pelaksana proyek PT. Waskita Karya Basuki Brahmanta Putra Join Operation. Konflik ini disebabkan masyarakat sebagai pihak yang dirugikan karena pengerjaan proyek yang menimbun irigasi tradisional mereka (Banda Sampik), sehingga menyebabkan sawah dan kolam ikan mereka yang rusak dan mengalami kekeringan dalam kurun waktu yang cukup lama sawah mereka tidak bisa memproduksi padi serta tidak ada pembayaran ganti rugi kepada masyarakat pasca kejadian ini. Hal ini 
yang kemudian memicu konflik antara masyarakat dengan perusahaan pelaksana proyek irigasi. Masyarakat pun melakukan aksi perlawanan seperti penutupan jalan menuju lokasi proyek dan melakukan aksi demontrasi kepada pihak perusahaan dan juga pemerintah.

Sampai saat ini konflik masyarakat dengan perusahaan pelaksana proyek irigasi masih berlanjut dan belum ada titik penyelesaian karena belum terpenuhi pemenuhan kebutuhan dan kepentingan. Saat kebutuhan dan kepentingan belum terpenuhi maka konflik akan terus terjadi dan berlanjut. Selanjutnya, Siahaan dalam (Astawa, 2015) menyatakan, para petani biasanya bersedia mengambil resiko dengan mengadakan konfrontasi langsung apabila tuntutan akan kebutuhan mereka melonjak tibatiba dan istitusi lokal dan nasional serta kondisi budaya dan budaya yang cendrung meminta mereka untuk menggunakan jubah kolektif. Dan hubungan petani dengan lahan tentunya sangat lah erat, karena petani adalah sebuah produsen, jika lahan mereka yang biasanya bisa memproduksi padi dengan baik, saat tidak bisa lagi memproduksi, hal tersebut berarti mengusik mereka sebagai tulang punggung hidupnya.

Penyelesaian konflik yang lambat akan menyebabkan terganggunya aktivitas masyarakat terutama dalam hal bercocok tanam dan berdampak terhadap kehidupan ekonomi masyarakat petani yang ada di Nagari Pangian serta dapat mengakibatkan retaknya kesatuan dalam kelompok, hancurnya harta benda bahkan menimbulkan korban jiwa. Sehubungan dengan paparan sebelumnya maka fokus artikel berkaitan dengan bagaimana strategi penyelesaian konflik irigasi di Kabupaten Tanah Datar yang sudah dilakukan. Fenomena ini sangat menarik untuk diteliti dengan maksud agar memperoleh suatu deskripsi yang utuh tentang cara penyelesaian konflik irigasi di Kabupaten Tanah Datar. Memperhatikan fenomena konflik tersebut, maka diperlukan sebuah strategi penyelesaian konflik yang diharapkan nantinya dapat menyelesaikan persoalan dengan baik. Strategi digunakan sebagai upaya untuk mencapai tujuan, sasaran dan kemenangan. Strategi menjadi sebuah elemen yang sangt penting dalam pencapaian suatu tujuan yang hendak dicapai.

\section{METODE PENELITIAN}

Penelitian ini dilaksanakan dengan menggunakan metode penelitian kualitatif deskriptif. Dengan penentuan lokasi di Nagari Pangian Kecamatan Lintau Buo Kabupaten Tanah Datar berdasarkan pertimbangan bahwa di Nagari tersebut adanya pengerjaan proyek Daerah Irigasi Batang Sinamar.

Informan penelitian menggunakan teknik purpusive sampling. Informan dipilih berdasarkan karakteristik orang-orang yang benar-benar memahami permasalahan yang peneliti teliti. Adapun yang menjadi informan dalam penelitian ini adalah, masyarakat petani, pihak perusahaan, wali jorong Koto Gadang, pihak wali nagari Pangian, camat Lintau Buo, Pemuda, tokoh masyarakat, ketua Kerapatan Adat Nagari, dan Perwakilan Suku Pangian.

Teknik pengumpulan data dilakukan melalui observasi, wawancara dan studi dokumentasi. 
Uji keabsahan data penulis menggunakan teknik trianggulasi sumber. Selanjutnya data yang diperoleh akan dianalisis melalui tahap reduksi data, penyajian data dan penarikan kesimpulan.

\section{HASIL DAN PEMBAHASAN}

\section{Strategi Penyelesaian Konflik Irigasi di Kabupaten Tanah Datar yang Dilakukan}

Sejak adanya pembangunan proyek Batang Sinamar dan merusak aliran irigasi tradisonal masyarakat (Banda Sampik), sawah dan kolam ikan masyarakat mengalami kekeringan sehingga tidak bisa memproduksi sawah selama bertahuntahun, dalam menyikapi hal tersebut masyarakat melakukan berbagai aksi perlawanan sebagai bentuk dari dampak yang ditimbulkan dengan adanya pembangunan proyek Batang Sinamar. Masyarakat melakukan aksi perlawanan untuk menuntut kerugian mereka dengan cara memblokir jalan menuju lokasi proyek, melakukan aksi demontrasi dan meminta pendampingan pada organisasi WALHI Sumatera Barat dan PBHI Sumatera Barat.

Dalam menyikapi permasalahan maka masyarakat petani nagari Pangian dan perusahaan menggunakan strategi yang berbeda, strategi yang digunakan tergantung pada proses konflik, jika ditemukan hal-hal baru mengenai kadaaan pihak yang satu, maka strategi yang digunakan akan berubah sesuai dengan perkembangan proses konflik. Namun, dalam penyelesaian konflik ini masyarakat dan pihak perusahaan lebih condong kepada cara penyelesaian konflik diluar pengadilan yaitu dengan menggunakan strategi Non-Litigasi melalui proses negosiasi. Menurut (Rohmad, Abu 2008) cara penyelesaian konflik Non-Litigasi adalah cara penyelesaian konflik yang dilakukan secara win-win solution, yang lebih mengutamakan musyawarah dan mufakat untuk kemenangan dan kesejahteraan bersama, yang dapat dilakukan didalam ataupun diluar pengadilan.

Strategi masyarakat petani Nagari Pangian untuk mendapatkan ganti rugi karena lahan mereka yang sudah terdampak cukup lama, menunjukkan sebuah bentuk variasi yang berbeda. Pada awalnya petani menggunakan cara damai dengan cara mengirimkan surat langsung kepada pihak perusahaan untuk segera menindaklanjuti dampak yang ditimbulkan pengerjaan proyek. Ternyata cara tersebut tidak mendapatkan tanggapan yang baik dari pihak perusahaan. Kemudian masyarakat petani mulai mengubah strategi mereka dengan cara melakukan konfrontasi dengan cara melakukan aksi penutupan jalan menuju lokasi proyek dan melakukan aksi demontrasi dalam rentang waktu tertentu. Kemudian masyarakat petani juga minta perdampingan kepada beberapa organisasi Lembaga Swadaya Masyarakat yaitu WALHI Sumatera Barat dan PBHI Sumatera Barat.

Dalam usaha mencegah meluasnya tindakan masyarakat, pihak perusahaan melakukan beberapa cara, yaitu a) pernah menjanjikan bahwa tuntutan mereka akan berusaha dipenuhi b) bersama pemerintah nagari dan kecamatan akan segera menyelesaikan tuntutan masyarakat. Namun, hingga saat ini 
ganti rugi belum dibayarkan oleh pihak perusahaan dan konflik masih terus berlanjut karena kebutuhan masyarakat belum terpenuhi. Hal ini didukung oleh pendapat (Mial Hugh dan Oliver Ramsbotham Woodhouse, 2000) menyatakan bahwa konflik yang sulit didamaikan apabila adanya pengabaian terhadap kebutuhan, dan konflik hanya bisa diselesaikan ketika kebutuhan dapat terpenuhi.

Semakin menguatnya perlawanan masyarakat, pihak perusahaan dan pemerintah melakukan strategi dengan cara melakukan perundingan dan negosiasi. Dalam hal tersebut pihak pemerintah nagari dan kecamatan melakukan pendekatan kepada pihak masyarakat pemilik lahan dan mengadakan pertemuan dengan masyarakat pemilik lahan agar tidak melakukan tindakan anarkis. Perundingan dan negosiasi ini dilakukan dengan melibatkan beberapa pihak mulai dari pemerintah nagari, kecamatan sampai pada pemerintah kabupaten. Perundingan ini dilakukan selama beberapa kali pertemuan dan rapat untuk guna menindaklanjuti tuntutan masyarakat petani terkait dengan persoalan ganti rugi.

Strategi penyelesaian konflik ini sesuai dengan pendapat (Ktut, Diara Astawa, 2015) bahwasanya ada 5 strategi penyelesaian konflik diantara:

1. Strategi bersaing, strategi bersaing merupakan sebuah usaha untuk memenuhi kelompok sendiri, serta tidak memperdulikan dampak yang akan dimunculkan terhadap pihak lawan. Akibatnya konflik yang ditimbulkan semakin tajam, desdruktif bahkan menimbulkan kekerasan dan penindasan terhadap pihak lawannya. Kondisi terjadi disebabkan karena kedua belah pihak mempunyai persepsi, kepentingan dan tujuan yang berbeda dan sukar memcapai konsensus (kebersamaan).

2. Strategi Kolaborasi, strategi kolaborasi merupakan upaya dan masing-masing pihak yang berkonflik untuk dapat memuaskan kepentingan semua pihak.

3. Strategi menghindar, strategi menghindar adalah upaya dari pihak yang berkonflik, menghindari setiap tawaran dari pihak lawan. Strategi ini, diterapkan oleh pihak dengan taktik, berpura-pura patuh, mengutus orang yang tidak terlibat konflik untuk menghadiri pertemuan dengan pihak lawan dan sebagainya. Strategi menghindar dilakukan tidak lepas dari adanya iming-iming, janjijanji dari pihak luar yang sanggup memperjuangkan kepentingan mereka.

4. Strategi mengakomodasi, strategi ini mengakomodasi merupakan kesedian dari salah satu pihak yang berkonflik untuk menaruh kepentingan lawan di atas kepentingannya.

Strategi penyelesain konflik yang diterapkan dalam konflik pembangunan irigasi ini ada 3 (tiga) strategi, yaitu starategi bersaing, menghindar dan kompromi. Strategi bersaing merupakan sebuah usaha untuk memenuhi kelompok sendiri dan tidak memperdulikan dampak yang terjadi terhadap pihak lawan, yang mengakibatkan konflik semakin memanas dan bahkan menimbulkan 
kekerasan dan juga penindasan terhadap pihak lawan. Hal ini terjadi karena kedua belah pihak memiliki kebutuhan dan kepentingan yang berbeda, tujuan serta persepsi yang berbeda satu dengan yang lain. Strategi menghindar, strategi yang dilakukan oleh pihak perusahaan, janji untuk memperjuangkan kebutuhan dan kepentingan masyarakat. Kemudian, strategi kompromi, upaya untuk mempertemukan kepentingan kedua pihak dengan cara melakukan perundingan damai melalui proses negosiasi, hal ini dibuktikan dengan beberapa kali diadakan pertemuan oleh pemerintahan dan perusahaan serta juga melibatkan perwakilan dari masyarakat dan juga pihak perusahaan dan juga pemerintah nagari, kecamatan dan juga kabupaten agar kebutuhan dan kepentingan kedua pihak segera terpenuhi. Hingga saat ini penyelesain konflik ini masih dalam tahap kompromi yang melibatkan berbagai elemen-elemen terkait.

Masyarakat petani dan pihak perusahaan dan juga pemerintah dalam konflik ini memilih cara penyelesaian konflik secara NonLitigasi (diluar pengadilan) dan menghindari cara litigasi (hukum) hal ini dilakukan dengan cara negosiasi, dan juga musyawarah. Cara ini dilakukan bahwa masyarakat petani Nagari Pangian bersedia diajak berbicara, berdialog dan juga berkompromi. Hal tersebut dibuktikan dengan beberapa kali diadakan perundingan. Pihak perusahaan juga bisa melaksanakan pengerjaan proyek dengan lancar tanpa ada gangguan dari dilapangan sehingga progres yang ditentukan dapat terselesaikan sesuai dengan target yang telah ditentukan.
Berikut tabel perundingan yang dilakukan oleh perusahaan, dan juga pemerintah, sebagai berikut: Tabel 1.

Rekapitulasi Perundingan yang dilakukan

\begin{tabular}{|c|c|c|}
\hline No & Tanggal & Rapat \\
\hline 1. & $\begin{array}{l}6 \text { November } \\
2017\end{array}$ & $\begin{array}{l}\text { Melakukan } \\
\text { kepada pendekatan } \\
\text { pemilik masyarakat } \\
\text { mengadakan pertemuan } \\
\text { dengan dan } \\
\text { kelompok masyarakat }\end{array}$ \\
\hline 2. & $\begin{array}{l}6 \text { November } \\
2017\end{array}$ & $\begin{array}{l}\text { Pihak } \\
\text { memfasilitasi pertemuan } \\
\text { antara pihak masyarakat } \\
\text { dengan pihak Proyek DI } \\
\text { Batang Sinamar tentang } \\
\text { perbaikan saluran irigasi } \\
\text { dan ganti rugi bagi } \\
\text { masyarakat korban yang } \\
\text { tidak bisa bercocok tanam }\end{array}$ \\
\hline 3. & 24 Juli 2018 & $\begin{array}{l}\text { Menindaklanjuti surat } \\
\text { petani terdampak proyek } \\
\text { irigasi batang sinamar , } \\
\text { perihal tuntutan ganti rugi } \\
\text { ada, bertempat di ruang } \\
\text { rapat Sekda Batusangkar }\end{array}$ \\
\hline 4. & 31 Juli 2018 & $\begin{array}{l}\text { Penyelesaian surat petani } \\
\text { korban terdampak proyek } \\
\text { DI Batang Sinamar Nagari } \\
\text { Pangian Kec. Lintau Buo } \\
\text { Kab. Tanah Datar, } \\
\text { bertempat di ruang rapat } \\
\text { Sekda Batusangkar peserta } \\
\text { rapat Kepala BWSS V } \\
\text { Sumatera Barat, PPK Irigasi } \\
\text { dan Rawa I-SNVT Prov. } \\
\text { Sumbar, Kepala Dinas } \\
\text { PUPR dan Pertanahan Kab. } \\
\text { Tanah Datar, Kepala } \\
\text { Baperlitbang Kab. Tanah } \\
\text { Datar, Kabag POD, Kabag } \\
\text { Hukum, Kabag } \\
\text { Administrasi Camat } \\
\text { Pembangunan, Wan } \\
\text { Lintau Buo, dan Wali } \\
\text { Nagari Pangian }\end{array}$ \\
\hline 5. & 8 Januari 2019 & $\begin{array}{l}\text { Menindaklanjuti persoalan } \\
\text { pembayaran ganti rugi } \\
\text { petani korban terdampak } \\
\text { proyek DI Batang Sinamar } \\
\text { Nagari Pangian Kec. Lintau } \\
\text { Buo Kab. Tanah Datar } \\
\text { dihadiri oleh dinas } \\
\text { pertanian, dan pihak } \\
\text { kecamatan. }\end{array}$ \\
\hline
\end{tabular}


Dalam konflik ini adanya kebutuhan dan kepentingan yang saling bertolak belakang antara kedua belah pihak. Setiap orang memiliki kebutuhan, kebutuhan yang dimiliki setiap orang berbeda antara satu dengan yang lain, jika kebutuhan tidak dipenuhi maka hal ini dapat memicu terjadinya konflik. Hal ini sejalan dengan pendapat (Chandra, I Robby, 1992) menjelaskan bahwa kebutuhan yang berbeda-beda dan bersamaan diantara dua pihak atau lebih secara potensial dapat menyebabkan dan memicu terjadinya konflik. Adapun kebutuhan dan kepentingan kedua belah pihak dalam konflik ini antara lain, dari masyarakat sebagai berikut:

1. Perbaiki irigasi tradisional yang telah rusak. Akibat pengerjaan proyek Daerah Irigasi Batang Sinamar yang dilakukan oleh pihak perusahaan irigasi tradisional masyarakat yang biasa mereka sebut dengan istilah banda sampik rusak. Rusaknya irigasi tersebut menyebabkan air yang biasanya digunakan untuk mengairi sawah dan lahan mereka tidak bisa masuk untuk mengairi lahan pertanian.

2. Memberikan dana untuk pembersiahan lahan. Masyarakat meminta kepada pihak perusahaan untuk segera memberikan dana guna untuk pembersihan lahan sawah mereka yang sudah ditumbuhi semak belukar pasca keringnya sawah dan kolom ikan yang terdampak.

3. Pembayaran ganti rugi. Masyarakat telah dirugikan bertahun-tahun karena adanya pembangunan proyek yang menimbun banda sampik sehingga berdampak besar terhadap kehidupan mereka, sawah mereka yang biasa ditanami padi tidak bisa lagi diproduksi karena sudah tidak ada lagi air yang masuk untuk mengairi sawah mereka. Kerugian yang terhitung dari tahun 2015-2018 segera dibayarkan oleh pihak perusahaan dan pemerintah.

Sementara kebutuhan dari pihak perusahaan adalah:

1. Menciptakan kerjasama dan hubungan yang baik dan harmonis dengan masyarakat. Pihak perusahaan dengan masyarakat bisa bekerjasama dengan baik, masyarakat diharapkan bisa menjadi partner yang baik sehingga kegiatan proyek dapat berjalan dengan lancar.

2. Adanya saling pengertian antara masyarakat dan pihak perusahaan agar segala kemungkinan dan resiko-resiko yang akan timbul dapat diselesaikan dengan baik.

3. Pengerjaan proyek DI Batang Sinamar bisa berjalan dengan lancar dan sesuai dengan rencana sesuai dengan target yang telah ditentukan.

Adapun yang menjadi kepentingan pihak perusahaan dalam konflik ini adalah tercapainya progres dan sasaran pengerjaan proyek DI Batang Sinamar, dengan sasaran yang hendak dicapai ialah terbangunnnya pengembangan air permukaan sebagai irigasi untuk mengairi lahan pertanian di Daerah Kecamatan Lintau Buo Kabupaten Tanah Datar. 
KESIMPULAN

a. Cara penyelesaian konflik dilakukan dengan menggunakan cara Non-Litigasi yaitu penyelesain konflik diluar mekanisme pangadilan. Yang dilakukan melalui proses negosiasi. Dengan melibatkan masyarakat petani, perusahaan, pihak pemerintaha nagari, kecamatan, dan juga pihak kabupaten.

b. Kebutuhan dan kepentingan dalam konflik masyarakat petani Nagari Pangian dengan perusahaan pelaksana proyek Daerah Irigasi Batang Sinamar, adalah sebuah kebutuhan dan kepentingan untuk didengar dan dilihat, yaitu kebutuhan yang mana setiap orang ingin didengar dan dilihat, baik itu keluhan ataupun tuntutan terkait dengan perbaikan irigasi banda sampik yang telah sudah tidak bisa mengairi sawah, dana pembersihan lahan dan pembayaran ganti rugi akibat sawah yang tidak bisa diolah selama bertahun-tahun.

c. Kebutuhan dan kepentingan pihak perusahaan, kebutuhan dan kepentingan yang disebut dengan endurance yaitu, rintangan atau masalah yang ada dilapangan dapat diselesaikan dengan baik, diantaranya terciptanya kerjasama yang baik antara pihak perusahaan dengan masyarakat petani Nagari pangian, adanya rasa saling pengertian yang diberikan oleh masyarakat petani kepada pihak perusahaan dan kegiatan pembangunan proyek Daerah Irigasi Batang Sinamar bisa berjalan dengan lancar sesuai dengan rencana.

\section{DAFTAR PUSTAKA}

Astawa, Ktut Diara. (2015). Strategi Penyelesaian Konflik Tanah Perkebunan. No.1 Th. 28 Hal 4043

Chandra, Robby I. (1992). Konflik dalam hidup sehari-hari. Yogyakarta: Kanisius

Dokumen Evaluasi Lingkungan Hidup (DELH) tentang Pembangunan Daerah Irigasi Batang Sinamar Tahun 2010

Miall Hugh, Oliver Ramsbothan dan Tom Wooddhouse. (1999). Resolusi Damai Konflik Kontemporer. Jakarta: PT Raja Grafindo Persada

Rohmad, Abu. (2008). Paradigma Resolusi Konflik Agraria. Semarang: Walisongo Press 